\title{
Entre precisão e rigor: a lupa de Luiz Cristiano de Andrade sobre a História do Brasil (1630) de Frei Vicente do Salvador
}

Between Precision and Accurecy: the magnifying glass of Luiz Cristiano de Andrade on História do Brasil (1630) by Frei Vicente do Salvador

ANDRADE, Luiz Cristiano de. A Narrativa da Vontade de Deus: a História do Brasil de frei Vicente do Salvador. Rio de Janeiro: FBN, 2014. 281p.

\section{Eduardo Sinkevisque}

esinkevisque@hotmail.com

Doutor pesquisador

PNAP-R - Fundação Biblioteca Nacional

Av. Rio Branco, 219 - Centro

20040-009 - Rio de Janeiro - RJ

Brasil

Palavras-chave

Historiografia; Ars historica; Catolicismo.

Keywords

Historiography; Ars histórica; Catholicism. 
A Narrativa da Vontade de Deus: a História do Brasil de frei Vicente do Salvador (2014, 288p.), de Luiz Cristiano de Andrade, com apresentação de Marcus Venicio T. Ribeiro, é daqueles livros em que os termos precisão e rigor podem ser aplicados. Fruto de uma dissertação de mestrado sob orientação de Andréa Daher (UFRJ/PPGHIS), defendida em 2004, o livro de Luiz Cristiano de Andrade analisa a História do Brasil (1630), de Frei Vicente do Salvador, tendo em vista não apenas as interpretações oitocentistas/novecentistas documentalista/positivista, mas principalmente o texto como gênero em sua forma e função. Como discurso demonstrativo-deliberativo, didático de estilo médio ou temperado.

No século XVII, história é, como dicionariza Rafael Bluteau, palavra derivada do grego eido ('vejo', que, no passado quer dizer 'sei'). "História é narração de cousas memoráveis, que tem acontecido em algum lugar, em certo tempo, \&, com certas pessoas, ou nações" (BLUTEAU 1712). Narrativa histórica, no século XVII, é subgênero do epidítico (ou demonstrativo) alto, com elementos do judiciário, que ajuizam o passado e do deliberativo, que aconselham os fazeres futuros contingentes.

Os meios palacianos e eclesiásticos, por onde a prosa de frei Vicente circulou, implicam a constituição de interlocutores para quem o sentido da história é providencial. Na base do discurso do frei, tem-se as coisas (res) presentes por meio do exemplo das passadas. Isso supõe metafísica teológico-político-retórica. Na metafísica de que frei Vicente participa, Deus é o fundamento 268 transcendente do poder do Estado. A história participa da identidade absoluta indeterminada de Deus, cujo sentido providencial revela Sua vontade em coisas, homens e eventos. Experiência que revela o ditado transcendente no pacto de sujeição e alienação da comunidade aos "dois corpos do Rei", o corpo terreno e o transcendente (KANTOROWICZ 1998).

Os procedimentos de leitura propostos pelo autor possibilitam reconstruir o funcionamento do gênero histórico. Luiz Cristiano de Andrade empenha-se justamente com precisão e rigor na empreitada de, arqueologicamente, reconstruir o funcionamento do texto. Ao investir na leitura e enfrentar a narrativa seiscentista de frei Vicente do Salvador, Luiz Cristiano nos oferece a primeira legibilidade normativa da História do Brasil (1630). Isto é, o trabalho mostra os modelos retóricos, teológico-políticos da história; trata da política católica portuguesa do século XVII, da "neo-escolástica", do "aristotelismo-tomista", da sociedade de corte. Aspectos de suma importância para esse estudo, agora publicado pela Biblioteca Nacional do Rio de Janeiro.

Luiz Cristiano sabe e demonstra que, para o gênero histórico, a analogia é utilizada para permitir o encontro do humano com o divino na história. Analogia tem sentido tomista de participação que as criaturas têm em Deus enquanto Seus efeitos. Ela é estabelecida, escolasticamente, na relação entre o natural e o divino, e utilizada no discurso como base para o "ornato", entre conceitos engenhosos e os sinais divinos no mundo, entre as figuras da técnica discursiva (colhida principalmente em Aristóteles) e as da providência. Esse é o tipo de prova da historiografia estudada. As provas são análogos de Deus que, em 
sentido tomista, levam à "verdade". A "verdade" proposta por meio da narrativa da História do Brasil (1630) é forjada por tópicas teológico-político-retóricas providenciais, associadas à relação paternal de Deus para com o povo. Vontade de Deus associada à providência, como eleição. Razão para o livro se chamar $A$ narrativa da vontade de Deus.

A obra de frei Vicente do Salvador fora encomendada por Manuel Severim de Faria, chantre da Sé de Évora, e permaneceu inédita até 1888 quando Capistrano de Abreu a editou, primeiro nos Anais da Biblioteca Nacional (vol. 13), segundo em uma edição crítica (1918). A História do Brasil (1630) tem como principais matérias, dispostas em cinco livros, descrição das gentes, árvores, animais e os modos como fora governado o Estado do Brasil e por quais governantes até 1627. Para além da descrição da terra, frei Vicente se ocupa das capitanias hereditárias, e de narrar as ações, sempre gloriosas, de seus governantes. Destaca-se, entre as matérias da História do Brasil (1630), a narrativa das ocupações holandesas no Estado do Brasil e sua interpretação providencial construtora do herege invasor.

Para frei Vicente do Salvador, como para letrados luso-brasileiros do século XVII, a guerra com holandeses foi gerada por meio do pecado. Como castigo ao pecado, o império português, ao menos parte dele, é ameaçado, invadido, ocupado, saqueado.

O livro de Luiz Cristiano de Andrade divide-se em três capítulos acrescidos de Introdução, Conclusão, ilustrações, Bibliografia (atualizada) e Anexo. O Anexo seleciona documentação relativa à edição da História do Brasil (1630) nos Anais da Biblioteca Nacional.

O primeiro capítulo ocupa-se da fortuna crítica do texto, com destaque para a leitura de Capistrano de Abreu. Ou seja, expõe e desconstrói a visão nacionalista que atribui a frei Vicente do Salvador o lugar de primeiro historiador brasileiro, autor de um texto que é documento da nacionalidade. Nos dizeres de Luiz Cristiano de Andrade:

[...] do mesmo modo, no Brasil, o funcionamento específico da historiografia oitocentista resultaria em um uma leitura anacrônica dos papeis coloniais, entendida ao longo do século XX. Essa leitura, ainda hoje [é] professada frequentemente [...]. O tratamento conferido pelo historiador cearense à História do Brasil foi considerado exemplar e inquestionável pelos especialistas que o sucederam [...] (ANDRADE 2014, p. 68).

O autor, neste sentido, toma Capistrano como problema historiográfico, "à medida que as noções românticas de nação e documento, aplicadas para compreensão do período colonial brasileiro" foram repetidas incansavelmente. (ANDRADE 2014, p. 68). Com isso Luiz Cristiano, desfaz mitos e anacronismos. Desnaturaliza, assim, a prática letrada que estuda.

O segundo capítulo trata dos preceitos da história, suas leis segundo Manuel Severim de Faria, dos Discursos Vários Políticos (1624), como verdade, clareza e juízo. O texto de Manuel Severim de Faria funciona para frei Vicente, e no livro de Andrade, como um "metatexto" (um comentário prescritivo) da dedicatória que 
frei Vicente faz a chantre da Sé de Évora. Clareza, qualidade de estilo, é traço de João de Barros, que frei Vicente emula. Verdade e juízo são categorias próprias do gênero histórico, em sua longuíssima duração, atualizadas nos textos.

O terceiro capítulo analisa a História do Brasil, utilizando decorosamente categorias teológico-político-retóricas de sua invenção tais quais: livre-arbítrio, graça, discórdia, concórdia, dissimulação honesta, bem-comum, guerra justa, prudência, razão de Estado.

Luiz Cristiano de Andrade faz crítica do documento. Não toma a narrativa da história como um dado ou evidência, mas reconstrói sua forma mentis. Ocupa-se das principais matérias da história e de sua interpretação segundo sentidos do século XVII. Como espelho de príncipes a história seiscentista, demonstrada por Andrade, atualiza as tópicas, as categorias mencionadas anteriormente, para ensino e deleite.

A dissertação, em livro, ganhou ilustrações do acervo da Biblioteca Nacional do Rio de Janeiro. Pertinentes, as imagens concorrem para historiar o trabalho. São imagens como: retrato de São Francisco de Assis (lembre-se de que frei Vicente do Salvador era franciscano), reprodução da folha de rosto do manuscrito da História do Brasil (1630), reprodução de mapas, entre outras.

Se fosse escolher uma lupa para aplicar sobre a História do Brasil (1630), escolheria, certamente, a lupa de Luiz Cristiano de Andrade. Ela evidencia um sentido verossímil para a construção, circulação e recepção da história no século XVII luso-brasileiro, em particular a história de frei Vicente do Salvador.

270 Despsicologiza, desmoraliza e desnacionaliza o objeto "colonial".

Assim como para frei Vicente do Salvador escrever história era batalhar, na chave letras e armas, para quem analisa uma das práticas letradas seiscentistas, a história, é necessário ser preciso e rigoroso. Isso o autor de $A$ Narrativa da Vontade de Deus: A História do Brasil de frei Vicente do Salvador demonstra ser em sua dissertação agora em livro.

\section{Referências bibliográficas}

ANDRADE, Luiz Cristiano de. A Narrativa da Vontade de Deus: a História do Brasil de frei Vicente do Salvador. Rio de Janeiro: FBN, 2014.

BLUTEAU, Rafael. Vocabulário português e latino (...). Colégio das Artes da Companhia de Jesus: Coimbra, 1712. T. 4, p. 39-40.

KANTOROWICZ, Ernst H. Os dois corpos do rei: um estudo sobre teologia política medieval. Tradução de Cid Knipel Moreira. São Paulo: Companhia das Letras, 1998. 